\title{
PERAN MADU DALAM MENGHAMBAT PERTUMBUHAN BAKTERI PADA LUKA BAKAR
}

\author{
Nabila Abiyasa Putri ${ }^{1,}$ Ruby Riana Asparini ${ }^{2}$ \\ ${ }^{1}$ Mahasiswa Fakultas Kedokteran Universitas Airlangga \\ ${ }^{2}$ Staff Pengajar Fakultas Kedokteran Univ. Muhammadiyah Malang \\ J1. Bendungan Sutami No.188A Malang
}

Email : nabilabiyasa@gmail.com

\begin{abstract}
ABSTRAK
Luka bakar dapat didefinisikan sebagai luka yang disebabkan oleh api, air panas, kontak dengan material panas atau dingin, bahan kimia dan aliran listrik yang melewati jaringan. Luka bakar adalah tempat yang ideal bagi bakteri untuk berkembang biak karena lingkungan nutrisi yang hangat dan lembab.Pengobatan modern untuk mencegah timbulnya infeksi menggunakan silver sulfadiaze (SSD) namun beberapa penelitian menemukan bahwa penggunaan SSD dapat memperpanjang waktu penyembuhan luka. Sebagai pengobatan alternatif, madu dapat digunakan untuk mencegah infeksi tanpa memperpanjang waktu penyembuhan luka.

Madu mengandung sejumlah besar karbohidrat, lipid, asam amino, protein, vitamin dan mineral yang memiliki peran penting dalam penyembuhan luka. Madu juga mengandung beberapa senyawa organik, yang telah terindentifikasi antara lain seperti polyphenol, flavonoid, dan glikosida. Mekanisme madu sebagai antibakteri dapat diklasifikasikan secara langsung dan tidak langsung. Mekanisme secara langsung didasarkan pada kemampuan komponen madu untuk membunuh bakteri. Mekanisme secara langsung meliputi mekanisme terbentuknya hidrogen peroksida (H2O2), osmolalitas tinggi, $\mathrm{pH}$ rendah, faktor non - peroksida, dan fenol. Mekanisme tidak langsung adalah respon antibakteri dari host yang dirangsang oleh madu terhadap bakteri. Mekanisme antibakteri tidak langsung meliputi limfosit dan produksi antibodi, sitokin dan respon imun, dan nitrit oksida.
\end{abstract}

Kata Kunci : Madu, Luka Bakar, Pertumbuhan Bakteri

\section{ABTRACT}

Burn can be defined as wound caused by fire, hot water, contact with hot or cold material, chemical material and electricity that passed through tissues. Burn is an ideal place for bacteria to colonize due to its nutritionally rich environment. Modern therapy used to prevent infection is silver sulfadiazine (SSD), but some research found that the used of SSD can retard wound healing. Honey can be used as alternative therapy to prevent infection without extending wound healing.

Honey contain a large amount of carbohydrate, lipid, amino acid, protein, vitamin and mineral which possess important role in wound healing. Honey also contain some organic compound, some of it which has been identified is polyphenol, flavonoid and glycoside. Honey mechanism as antibacterial can be classified as direct and indirect. Direct mechanism is based on honey components ability in killing bacteria. This mechanism consists of the formation hydrogen peroxide (H2O2), high osmolality, low $\mathrm{pH}$, non-peroxide factor and fenol. Indirect mechanism is host antibacterial response which honey help stimulate. This mechanism consist of lymphocyte, antibody production, cytokine, immune response and nitrite oxide.

Key Words : Honey, Burn, Bacteria colonization. 


\section{PENDAHULUAN}

Luka bakar dapat didefinisikan sebagai luka yang disebabkan oleh api, air panas, kontak dengan material panas atau dingin, bahan kimia dan aliran listrik yang melewati jaringan (American Burn Association, 2011). Luka bakar menurut kedalaman dapat dibagi menjadi tiga.Luka bakar superficial (grade I) hanya sedalam epidermis.Luka bakar partial-thickness (grade II) terbagi menjadi 2 tipe, superficial partial-thickness (grade IIA) dan deep partial-thickness (grade IIB).Luka bakar tipe superficial partial-thickness kedalamannya meliputi epidermis dan bagian atas dermis, sedangkan luka bakar tipe deep partial-thickness adalah meliputi epidermis dan sebagian dermis.Luka bakar fullthickness (grade III) kedalamannya meliputi epidermis dan dermis (American Burn Association, 2011).

Semakin lama luka terbuka, jaringan hipo perfusi atau nekrotik, semakin mudah bagi bakteri untuk kolonisasi. Bahkan, luka adalah tempat yang ideal bagi bakteri untuk berkembang biak karena lingkungan nutrisi yang hangat dan lembab.

Bakteri dalam kadar rendah juga dapat menunda penyembuhan luka sebelum invasi jaringan melalui sekresi toksin baik secara langsung dari sel yang vital (eksotoksin) atau sebagai akibat dari sel lisis (endotoksin). Toksin ini menyebabkan nekrosis lokal dan mengganggu keseimbangan mediator penting seperti sitokin dan protease yang diperlukan untuk penyembuhan. Oleh karena itu kontrol atau penyerapan cairan toksin adalah salah satu hal penting dalam modalitas pengendalian infeksi.

Perawatan luka bakar sudah berkembang secara pesat.Pengobatan modern untuk mencegah timbulnya infeksi menggunakan silver sulfadiaze (SSD).Namun beberapa penelitian menemukan bahwa penggunaan SSD dapat memperpanjang waktu penyembuhan luka (Subrabmanyam, 1998; Moore et al., 2001).Sebagai pengobatan alternatif, madu dapat digunakan untuk mencegah infeksi tanpa memperpanjang waktu penyembuhan luka.

\section{Madu sebagai terapi pada luka bakar}

a. Sejarah dan latar belakang

Gagasan menggunakan madu sebagai pengobatan luka bukanlah hal baru. Salep luka yang mengandung madu disebutkan dalam papirus
Mesir dari sebelum tahun 2000 SM. Berbagai penelitian yang dilakukan pada manusia menemukan bahwa madu efektif dalam membersihkan luka yang terinfeksi, membantu mencegah luka menjadi terinfeksi (Green, 1988), jaringan nekrotik dengan cepat tergantikan oleh jarigan granulasi (Subrabmanyam, 1998) dan mempercepat penyembuhan luka (Dumronglert, 1983).

Madu mempunyai sifat-sifat yang mendorong penyembuhan luka seperti agen antibakteri, mendorong autolytic debridement, merangsang pertumbuhan jaringan luka dan memulai aktivitas anti inflamasi yang dengan cepat mengurangi rasa sakit, edema dan produksi eksudat (Oryan et al., 2016).

Penggunaan madu sebagai terapi antibakteri sampai saat ini belum menghasilkan strain bakteri yang resisten. Penjelasan yang mungkin untuk hal ini adalah sifat antibakteri dari madu yang multifaktorial atau mempengaruhi lebih dari satu situs target (Labban, 2014). Pengaturan konsentrasi madu sebagai antibakteri secara efektif dapat membantu menghambat munculnya strain bakteri yang resisten (Oryan et al., 2016).

b. Kandungan madu

Madu mengandung sejumlah besar karbohidrat, lipid, asam amino, protein, vitamin dan mineral yang memiliki peran penting dalam penyembuhan luka (Oryan et al., 2016). Karbohidrat utama yang terkandung dalam madu adalah fruktosa (sekitar $38 \%$ ) dan glukosa (sekitar $31 \%$ ). Terdapat pula karbohidrat lain seperti sukrosa (sekitar 1\%) serta disakarida dan oligosakarida yang lain. Mineral yang terkandung dalam madu antara lain adalah potassium (jumlahnya terbanyak), $\mathrm{Ca}, \mathrm{P}, \mathrm{Fe}, \mathrm{Mg}$, dan Mn. Vitamin yang terkandung dalam madu antara lain vitamin $\mathrm{E}$ dan vitamin $\mathrm{C}$ serta vitamin B1, B2 dan B6. (Manyi-Lob et al., 2011).

Madu juga mengandung beberapa senyawa organik, yang telah terindentifikasi antara lain seperti polyphenol, flavonoid, dan glikosida (Alvarez-Suarez et al., 2014). Beberapa jenis enzim juga terkandung dalam madu, enzim tersebut bertanggung jawab merubah nektar yang sudah dikumpulkan oleh lebah menjadi madu. Enzim yang terdapat pada madu antara lain enzim glukosa amilase dan enzim invertase, kedua enzim ini membantu memecah glikogen menjadi unit yang lebih kecil. Terdapat 
pula enzim glukosa oksidase yang mengubah glukosa menjadi hidrogen peroksida dan asam glukonik (Gangwar, 2016).

\section{c. Aktivitas antibakteri}

Mekanisme madu sebagai antibakteri dapat diklasifikasikan secara langsung dan tidak langsung (Al-Waili et al., 2011).Mekanisme secara langsung didasarkan pada kemampuan komponen madu untuk membunuh bakteri.Mekanisme tidak langsung adalah respon antibakteri dari host yang dirangsang oleh madu terhadap bakteri.Mekanisme secara langsung mekanisme terbentuknya hidrogen peroksida (H2O2), osmolalitas tinggi, $\mathrm{pH}$ rendah, faktor non - peroksida, dan fenol.Mekanisme antibakteri tidak langsung meliputi limfosit dan produksi antibodi, sitokin dan respon imun, dan nitrit oksida (Ball, 2007).

i. Glukosa oksidase

Glukosa oksidase dapat mengubah glukosa menjadi hidrogen peroksida dan asam glukonat dalam suasana aerobik (Kwakman \& Zaat, 2012). Studi menemukan bahwa madu yang lebih terkonsentrasi menghasilkan lebih sedikit hidrogen peroksida, dan akumulasi hidrogen peroksida terbanyak terdapat pada madu yang konsentrasinya $30 \%$ - 50\%. Madu dengan konsetrasi 75\% memiliki aktivitas enzim glukosa oksidase yang suboptimal.Data ini menunjukkan bahwa madu dengan konsentrasi yang tergolong rendah $(30 \%$ $50 \%$ ) lebih cocok digunakan untuk perawatan luka (Bang et al., 2003).

ii. Hidrogen peroksida

Hidrogen peroksida adalah salah satu faktor utama madu dapat menghasilkan aktivitas antibakteri.Hidrogen peroksida secara perlahan dibentuk karena interaksi antara eksudat luka dengan glukosa oksidase yang terkandung didalam madu (Kwakman \& Zaat, 2012).

Madu juga mengandung asam askorbat yang membantu hidrogen peroksida melaksanakan tugasnya sebagai antibakteri.Studi menemukan bahwa campuran hidrogen peroksida dan asam askorbat meningkatkan lisis dan kematian bakteri Gram negatif oleh lisosom (Al-Waili et al., 2011).Hidrogen peroksida juga ditemukan dapat menarik leukosit ke luka melalui mekanisme gradien konsentrasi.Tidak hanya efek antibakteri, hidrogen peroksida juga dapat merangsang prolferasi fibroblast dan angiogenesis (Ball, 2007).

Faktor-faktor seperti panas (madu stabil pada suhu 50 oC, rusak pada suhu 55$70{ }^{\circ} \mathrm{C}$, cahaya ultraviolet, Methylglyoxal (MGO), enzim katalase dan auto-oksidasi dari flavonoids dapat menginaktivasi hydrogen peroksida (Brudzynnski et al., 2011).

iii. Methylglyoxal (MGO)

Methylglyoxal (MGO) merupakan antibakteri yang kuat tetapi dapat menekan pembentukan hidrogen peroksida karena Methylglyoxal (MGO) lebih reaktif berikatan dengan glukosa oksidase.Methylglyoxal (MGO) berasal dari konversi non - enzimatik dihidroksiaseton.Reaksi ini terjadi dalam nektar dan meningkat isinya dengan penyimpanan madu pada suhu $37{ }^{\circ} \mathrm{C}$ (Al-Waili et al., 2011).Methylglyoxal (MGO) sebagai komponen antibakteri mampu berinteraksi dengan pusat-pusat nukleofilik makromolekul seperti DNA. Dalam organisme Gram positif, Methylglyoxal (MGO) menurunkan regulasi enzim autolisin yang terlibat dalam pembelahan dinding sel bakteri pembelahan sel. Pada bakteri Gram negatif, Methylglyoxal (MGO) mengatur ekspresi gen yang terlibat dalam stabilitas dinding sel (Dart et al., 2015).

iv. Osmolaritas

Osmolaritas (jumlah partikel zat terlarut per liter larutan) madu yang tinggi merupakan komponen penting yang membantu membatasi pertumbuhan dan proliferasi bakteri (Al-Waili et al., 2011). Tingkat karbohidrat yang tinggi seperti fruktosa, glukosa, maltose, sukrosa dan bentuk karbohidrat yang lain bertanggung jawab untuk tingginya osmolaritas madu (Ruttermann et al., 2013). Glukosa dan karbohidrat dapat mengikat molekul air (Moore et al., 2001). Hal ini menyebabkan bakteri tidak mendapatkan cukup air untuk tumbuh.Akhirnya bakteri menjadi dehidrasi dan kemudian mati. 
v. Tekanan osmotic

Tekanan osmotik (tekanan yang dibutuhkan untuk mempertahankan keseimbangan osmotik) madu juga membantu mengeluarkan cairan limfatik dari jaringan subkutan ke luka.Cairan limfatik membantu menyingkirkan debris, jaringan nekrotik dan jaringan yang non-vital (Alam et al., 2014).

vi. $\mathrm{pH}$ madu

Rentang pH madu adalah 3,2-45 yang menandakan bahwa madu termasuk asam.Keasaman madu disebabkan adanya asam glukonat yang merupakan hasil reaksi glukosa oksidase dengan glukosa (Bittmann et al., 2010). Madu menyediakan lingkungan asam yang tidak menguntungkan bagi pertumbuhan bakteri dan menghambat aktivitas banyak mikro - organisme (Brudzynski et al., 2011).

vii.Meningkatkan aktivitas limfatik dan fagositosis

Madu dapat menstimulasi Blimfosit dan T-limfosit serta mengaktivasi neutrophil yang bertugas memfagositosis bakteri (Singh et al., 2012). Madu juga menstimulasi sekresi sitokin yang menginduksi penyembuhan luka, tumor necrosis factor-á (TNF-á), interleukin-1 (IL-1) dan interleukin6 (IL-6) yang mengaktivasi respon imun terhadap infeksi (Molan, 2002). Studi secara in-vitro -menemukan bahwa tingkat toksisitas madu terhadap keratinosit dan fibroblast sangatlah rendah (Burlando \& Cornara, 2013). Mekanisme madu dalam penyembuhan luka dapat dilihat pada gambar 1.

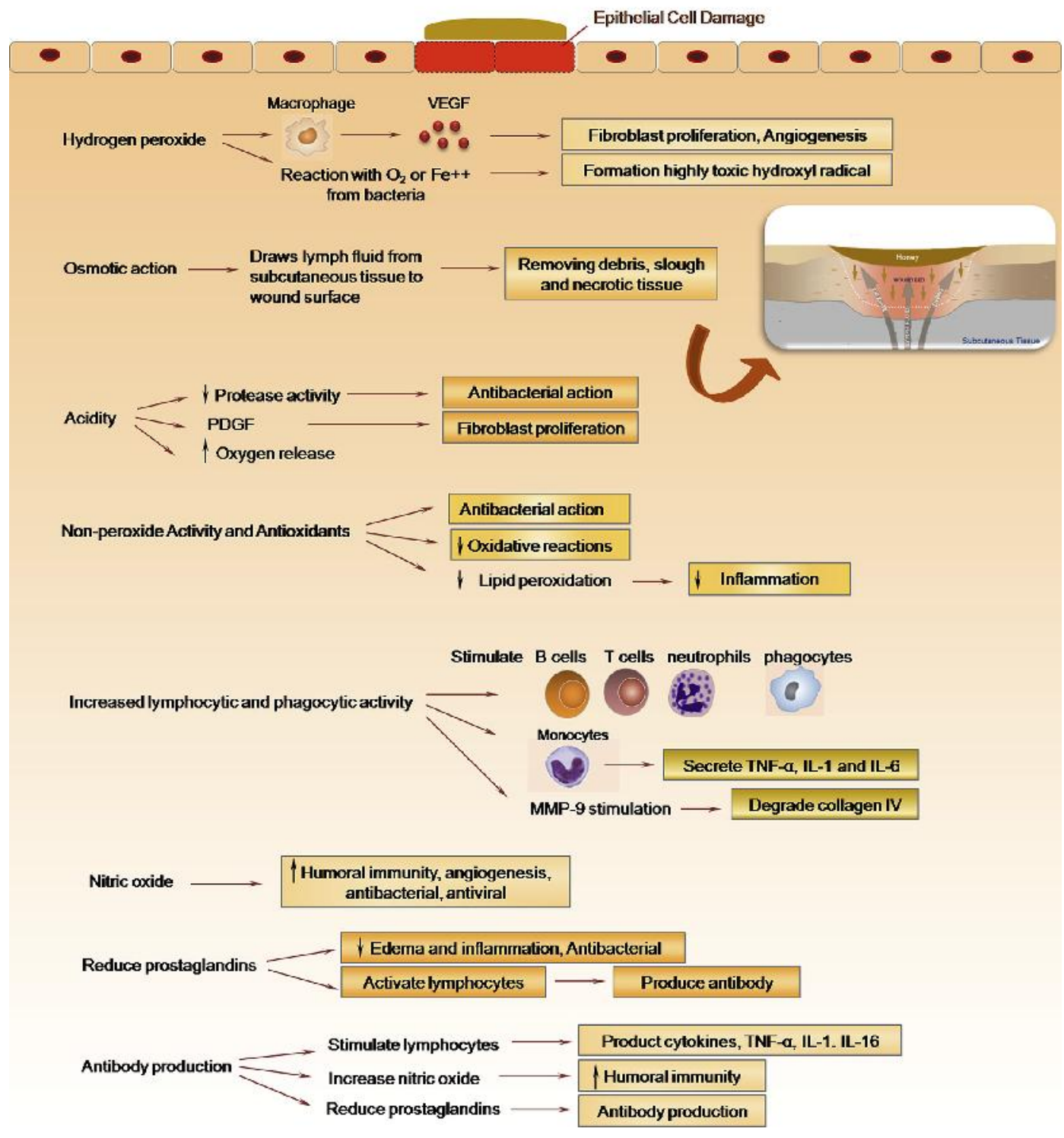


Gambar 1. Mekanisme kerja madu pada penyembuhan luka (Oryan et al., 2016)

\section{d. Debridement}

Debridement adalah kebutuhan dasar untuk memfasilitasi penyembuhan jaringan yang fungsional (Klein, 2007).Penggunaan madu sebagai dressingmembantu menciptakan lingkungan yang lembab sehingga debridement dapat terinduksi (Sukur et al., 2011).Hal ini terjadi karena tingginya tekanan osmotic madu serta aktivasi dari protease yang disebabkan oleh hidrogen peroksida (Manyi-Loh et al., 2011).Hal tersebut juga membantu melepaskan jaringan nekrotik tanpa menimbulkan rasa sakit.

e. Aktifitas anti-inflamasi

Inflamasi merupakan respon tubuh terhadap stimulus yang berbahaya serta memulai proses penyembuhan. Inflamasi juga merupakan penyebab utama nyeri dan edema pada luka (American Burn Association, 2011).Madu dapat mengurangi radikal bebas yang dihasilkan selama fase inflamasi sehingga mencegah timbulnya jaringan nekrotik yang berlebihan 105.Berkurangnya radikal bebas mengurangi aktivitas fibroblast, sehingga produksi kolagen juga berkurang. Hal ini meminimalisasi hingga mencegah terjadinya parut hipertofik 107

f. Stimulasi regenerasi dan perbaikan luka

Madu mengurangi edema, meredakan inflamasi dan nyeri, memfasilitasi debridement, mengurangi timbulnya bau, sintesis kolagen, terbentuknya pembuluh darah baru, stimulasi pertumbuhan fibroblast dan sel epitel, stimulasi terbentuknya jaringan granulasi dan mencegah terbentuknya parut dan keloid (Molan, 2002). Madu mempunyai peran untuk memodulasi fase inflamasi dari penyembuhan luka sehingga fase inflamasi tidak berlangsung terlalu lama/kronis (Raynaud et al., 2013).

\section{DAFTAR PUSTAKA}

Alam, F., Islam, M., Gan, S. \& Khalil, M., 2014. Honey: a potential therapeutic agent for managing diabetic wounds.

Alvarez-Suarez, J.M. et al., 2014. The Composition and Biological Activity of Honey: A Focus on Manuka Honey. Foods, 3, pp.420-32.

Al-Waili, N., Salom, K., Butler, G. \& Al Ghamdi, A., 2011. Honey and microbial infections: a review supporting the use of honey for microbial control.. 14(10).

American Burn Association, 2011. American Burn Association Advanced Burn Life Support Course Provider Manual. pp.114-15.

Ball, D.W., 2007. The Chemical Composition of Honey. Journal of Chemical Education, 84(10), p.1643.

Bang, L., Buntting, C. \& Molan, P., 2003. The effect of dilution on the rate of hydrogen peroxide production in honey and its implications for wound healing. 9(2).

Bittmann, S. et al., 2010. Does honey have a role in paediatric wound management? 19(15).

Brudzynski, K., Abubaker, K., St-Martin, L. \& Castle, A., 2011. Reexamining the role of hydrogen peroxide in bacteriostatic and bactericidal activities of honey. 2.

Burlando, B. \& Cornara, L., 2013. Honey in dermatology and skin care: a review. 12(4).

Dart, A., Bischofberger, A., Dart, C. \& Jeffcott, L., 2015. A review of research into second intention equine wound healing using manuka honey: current recommendations and future applications.

Dumronglert, E., 1983. Follow-up Study of Chronic Wound Healing Dressing With Pure Natural Honey. Journal of the National Research Council of Thailand, 15(2), pp.39-66.

Gangwar, S.K., 2016. Honey Physio-Chemical Parameters And Its Application With Reference To Ethiopia. International Journal of Science and Nature, 7(1), pp.16-24.

Green, A.E., 1988. Wound healing properties of honey. BJS Society Ltd, 75(12), p.1278.

Klein, M.B., 2007. Thermal, Chemical, and Electrical Injuries. In Thorne, C.H. et al. Grabb and Smith's Plastic Surgery. Wolters Kluwer Health. pp.132-49.

Kwakman, P. \& Zaat, S., 2012. Antibacterial components of honey. 64(1).

Labban, L., 2014. Honey as a promising treatment for diabetic foot ulcers (DFU). 28(2).

Manyi-Loh, C., Clarke, A. \& Ndip, R., 2011. An overview of honey: therapeutic properties and contribution in nutrition and human health. 5(8). 
Molan, P., 2002. Re-introducing honey in the management of wounds and ulcers e theory and practice. $48(11)$.

Moore, O. et al., 2001. Systematic review of the use of honey as a wound dressing. 1.

Oryan, A., Alemzadeh, E. \& Moshiri, A., 2016. Biological properties and therapeutic activities of honey in wound healing: A narrative review and meta-analysis. 25(2).

Raynaud, A. et al., 2013. Honey-induced macrophage stimulation: AP-1 and NF-kB activation and cytokine production are unrelated to LPS content of honey. 17(3).

Ruttermann, M., Maier-Hasselmann, A., NinkGrebe, B. \& Burckhardt, M., 2013. Local treatment of chronic wounds : inpatients with peripheral vascular disease, chronic venous insufûciency, and diabetes. 110(3).

Singh, M. et al., 2012. Honey as complementary medicine: a review. 3(2).

, M., 1998. A prospective randomised clinical and histological study of superficial burn wound healing with honey and silver sulfadiazine. Burns, 24(2), pp.157-61.

Sukur, S., Halim, A. \& Singh, K., 2011. Evaluations of bacterial contaminated full thickness burn wound healing in Sprague Dawley rats treated with Tualang honey. 44(1). 